\title{
Copper and silicon mediated, HMPA-free, $n+3$ ring expansions for the construction of medium sized lactones and lactams: short synthesis of $(+)$-cis-Lauthisan
}

\author{
Gary H. Posner, ${ }^{a}$ Mark A. Hatcher, ${ }^{b}$ and William A. Maio ${ }^{c^{*}}$ \\ ${ }^{a}$ Department of Chemistry, Johns Hopkins University, Baltimore, MD 21210, United States \\ ${ }^{b}$ GlaxoSmithKline, 5 Moore Drive, Research Triangle Park, NC 27709, United States \\ ${ }^{c}$ Department of Chemistry and Biochemistry, New Mexico State University, Las Cruces, NM 88003, United States \\ *wmaio@nmsu.edu
}

\section{ARTICLE INFO}

Article history:

Received

Received in revised form

Accepted

Available online

Keywords:

Medium Sized Lactones

Ketone Enolates

Epoxide Ring Opening

Ring Expansion

Total Synthesis
In this report, several new epoxide examples were united with $\beta$-silyl ketone enolates for the construction, after oxidative fragmentation, of ring expanded lactones, $\mathrm{n}+3$ atoms in size. Importantly, azido lactones were found to be valuable in an extension of this protocol involving the $n+3+p$ expansion into a series of hydroxy olefinic lactams. We also document a short, stereoselective total synthesis of (+)-cislauthisan and a new, cuprate-mediated and HMPA-free procedure for the generation of $\beta$-silyl silylenol ethers, useful in the environmentally-friendly construction of medium sized lactones.

\section{Introduction}

Pursuing our interest in epoxide ring opening reactions for the construction of medium sized lactones ${ }^{1}$ and lactams, ${ }^{2}$ we initiated a detailed investigation into our three-step, silicon-mediated $n+3$ ring expansion process with respect to substrate scope and overall efficiency. For example, the major advantage of this method over our previously reported two-step procedure ${ }^{3}$ was the replacement of toxic tin and lead reagents $\left[\mathrm{LiSnBu}_{3}\right.$ and $\mathrm{Pb}(\mathrm{OAc})_{4}$, respectively] with environmentally-friendly sources of silicon $\left(\mathrm{Me}_{3} \mathrm{SiLi}\right)$ and hypervalent iodine $\left[\mathrm{PhI}(\mathrm{OAc})_{2}, \mathrm{I}_{2}\right]$. Unfortunately, however, in order to generate the requisite $\beta$-silyl enolate, it was necessary to employ hexamethylphosphoramide (HMPA); a polar aprotic solvent which is known to be highly toxic. Also of note, a comprehensive substrate scope, in terms of reactive functionality on the epoxide sidechain, was not undertaken in either of our initial reports. Herein, we address both of these deficiencies and also provide a showcase for this method with the synthesis of ring expanded lactams and the stereoselective construction of $(+)$-cis-lauthisan.

\section{Mechanistic Investigations}

As mentioned above, the success of our $n+3$ ring expansion method relies upon the use of hypervalent iodine to fragment $\beta$ silyl hemiketal intermediates (cf. 1, Scheme 1), formed via the union of $\beta$-silyl ketone enolates with epoxides, into lactones (cf.
2) with exclusively $\mathrm{C}(5)-\mathrm{C}(6)$ cis-alkene geometry ( $\mathrm{n}=5$ and 6 ). Said differently, when utilizing either cyclopent- or cyclohexenone as starting material, despite the trans-orientation between the hydrogens of their corresponding $\beta$-silyl hemiketals, we have not observed any trans-alkene containing lactone products.

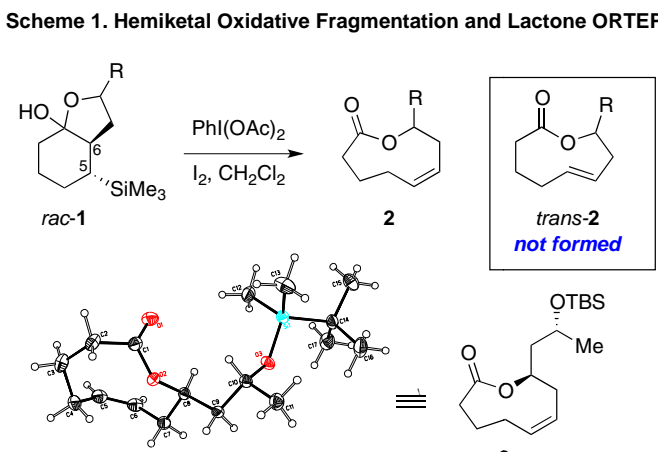

2a

The observed stereochemical preference for this reaction was initially somewhat of a mystery, especially when one considers the anionic fragmentation mechanism that was operative in our earlier work $^{3}$ and led to trans-alkenes as major products. Importantly, the cis-geometry was unambiguously confirmed in two ways: (1) via calculation of the alkene proton coupling 
constant $(J=\sim 10 \mathrm{~Hz})$ of the resultant acyclic diols obtained after DIBAl-H reduction, and (2) the X-ray crystal structure of lactone 2a which is representative of the 9-membered ring series (Scheme 1). On a related note, to the best of our knowledge, there have been no other literature reports that exploit the Suárez reaction conditions $\left[\mathrm{PhI}(\mathrm{OAc})_{2}, \mathrm{I}_{2}\right]^{4}$ for the oxidative fragmentation of a $\beta$-silyl hemiketal such as $\mathbf{1}$.

After considering these data, as well as several literature reports concerning similar fragmentation reactions, ${ }^{5}$ we now propose the following, nonconcerted, fragmentation mechanism to account for cis-alkene formation (Scheme 2). In the absence of photochemical irradiation, hypoiodite $\mathbf{3}$, formed upon the sequential addition of $\mathrm{PhI}(\mathrm{OAc})_{2}$ and $\mathrm{I}_{2}$ to a solution of 1 in $\mathrm{CH}_{2} \mathrm{Cl}_{2}$ at $0{ }^{\circ} \mathrm{C}$, homolytically cleaves to form oxygen-centered radical 4 which subsequently undergoes bond scission to generate a lactone carbonyl and $\beta$-silyl carbon centered radical 5. Previously, Kochi and coworkers observed that $\beta$-silyl radicals of this nature can be stabilized through hyperconjugation between the half filled radical p-orbital and the filled carbon-silicon $\sigma$-orbital. ${ }^{6}$ For this to occur in our system, carbon-carbon bond rotation must occur, resulting in an eclipsed conformation (6) before final fragmentation and olefin formation, orienting the $\mathrm{C}(5)-\mathrm{C}(6)$ hydrogens cis to one another in the product (Scheme 2).

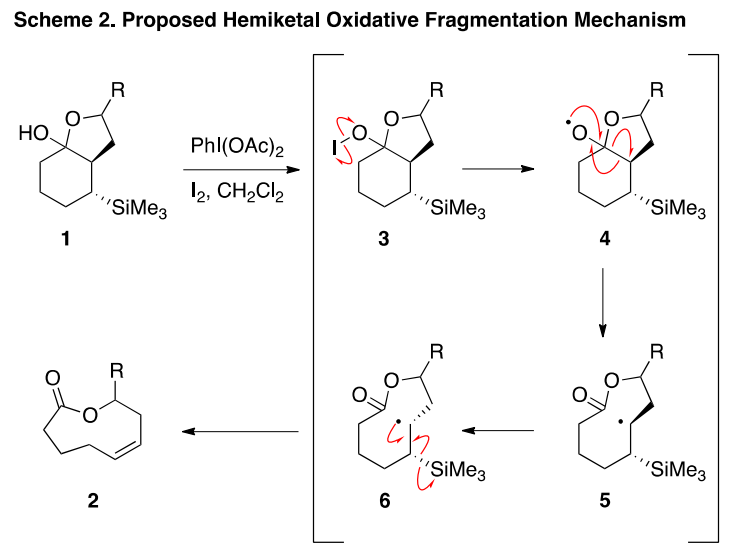

\section{Construction of Novel 8-Membered Lactones}

In addition to cyclohexenone, we have also reported that the $\beta$-silyl silylenol ether of cyclopentenone (7) can be exploited for the synthesis of 8-membered (5+3) lactones (cf. 9, Scheme 3). ${ }^{1}$ However, while reexamining our initial work, the substrate scope seemed somewhat limited, with silyl and benzyl protected alcohols the only reported functional groups tolerant of the two-step procedure. We now wish to report several additional reactive moieties that can survive both the epoxide opening step and subsequent oxidative fragmentation conditions (Scheme 3).

Several epoxide examples ${ }^{7}$ in Scheme 3 are noteworthy. In addition to chiral, non racemic epoxides (cf. 9a), ${ }^{8}$ masked amine functionality, notably terminal nitriles $(\mathbf{9 b})$, aromatic nitro groups (9c), and azides (9d-e) are exceedingly competent. Two step yields for these lactones are generally good with the notable exception being allyl cyanide oxide, where the poor yield may be attributed to epoxide volatility and / or $\alpha$-proton acidity.

Related to this study, we also united two new epoxide examples with the enolate corresponding to 6-membered enol ether 10 (Scheme 4). ${ }^{1}$ Not surprisingly, 4-azidobutene oxide produced the desired lactone in comparable yield to 7 (cf. $\mathbf{2 b}$ vs. 9d),
Scheme 3. 5+3 Ring Expansion for the Construction of 8-Membered Rings

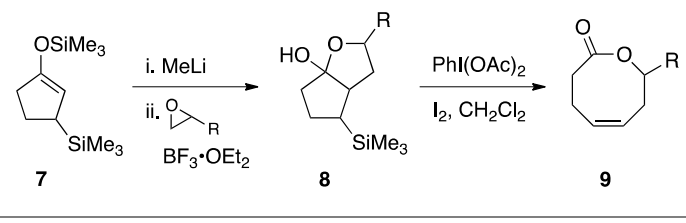

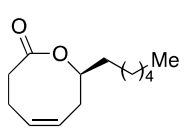

9 a, $59 \%$

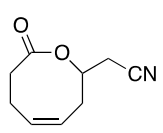

$9 b, 23 \%$

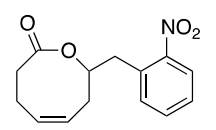

$9 c, 52 \%$

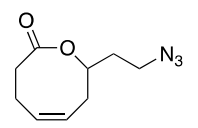

9d, $45 \%$

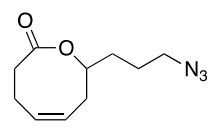

9 e, $48 \%$ while a terminal aliphatic nitro group with acidic $\alpha$-protons was also surprisingly able to withstand the reaction conditions.

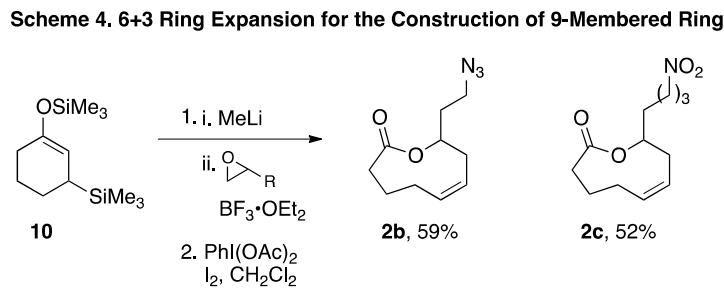

\section{Lactone to Lactam Ring Expansions}

In 2005, we published a short report regarding the sequential ring expansions of n-sized cycloalkenones into hydroxyolefinic $\mathrm{n}+3+\mathrm{p}$ sized lactones, ${ }^{1 \mathrm{~b}}$ where translactonization was efficiently triggered by fluoride mediated silyl ether cleavage. After the success of this work, we sought to develop an analogous protocol for the conversion of lactones into ring expanded lactams, especially in light of our related studies on the synthesis of $\delta$-lactams via lactone ring contraction. ${ }^{2}$ In a similar way, we had hoped that azido lactones 9d-e and $\mathbf{2 b}$ would serve as suitable substrates for this purpose. ${ }^{9}$

Initially, relying on the Corey method for azide reduction, ${ }^{10}$ lactone $2 \mathbf{b}$ was treated with hydrogen over the Lindlar catalyst (Scheme 5). While the desired chemoselective reduction did occur, concomitant intramolecular reorganization was not observed; primary amine $\mathbf{1 1}$ was isolated as the major organic product $(80 \%)$. This result is surprising, especially when one considers the transition state required for lactam formation is six atoms in size. A variety of subsequent reaction conditions were screened, for example: heat, microwave irradiation, base treatment $\left(\mathrm{Et}_{3} \mathrm{~N}\right.$ and $\mathrm{K}_{2} \mathrm{CO}_{3}$ ), and the addition of Lewis acids (e.g., $\mathrm{TiCl}_{4}, \mathrm{CeCl}_{3}, \mathrm{Me}_{3} \mathrm{Al}$, and $\mathrm{Al}_{2} \mathrm{O}_{3}$ ), but unfortunately, this intermediate could not be driven to the desired 11-membered lactam product.

Undeterred by these results, we next sought to exploit 8-membered azido lactones 9d and 9e in a similar process. Pleasingly, by switching to the Staudinger conditions $\left(\mathrm{PPh}_{3}\right.$ and $\left.\mathrm{H}_{2} \mathrm{O}\right)$, azide reduction was directly followed by lactone to lactam ring expansion (cf. 9d to 12 and 9e to 13) in good overall yield (Scheme 5). Unfortunately, when $\mathbf{2 b}$ was treated with these same conditions, 
lactone 11 was again isolated as the major organic product. While it is still unclear why amine $\mathbf{1 1}$ does not undergo ring expansion, one may argue that it could be due to the thermodynamic stability of a 9-membered lactone compared to the 11-membered lactam. ${ }^{11}$ Further investigations into the scope and limitations of this new, four-step, synthesis of medium-sized lactams is ongoing, and will be reported in due course.

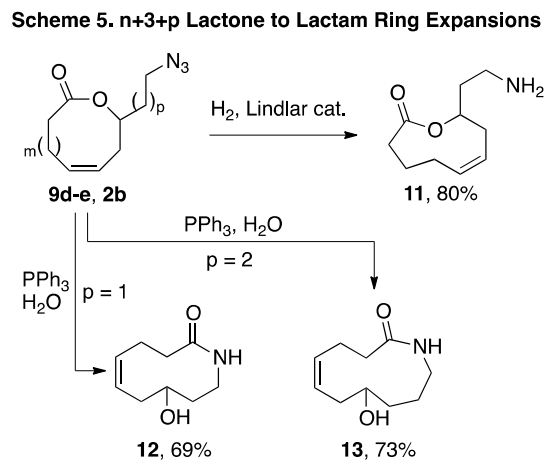

\section{Stereoselective Synthesis of (+)-cis-Lauthisan}

Previously, we have exploited our ring expansion protocol for the short and efficient syntheses of medium sized lactones and piperidines. ${ }^{1-2}$ As an extension of these studies, we now wish to report the use of a $5+3$ expansion as the key step in the total synthesis of $(+)$-cis-lauthisan [(+)-16], an easier to access saturated derivative of the marine derived cyclic ether $(+)-$ laurencin. ${ }^{12}$ Previous syntheses have suffered from long synthetic sequences (up to 18 steps), have been racemic, or proceeded with poor stereoinduction. ${ }^{13}$ A notable exception is a recent study by Urbano and Carreño which produced the optical enantiomer, (-)cis-lauthisan, in only four steps with high enantioselectivity via a reductive cyclization cascade. ${ }^{13 \mathrm{j}}$

By uniting our ring expansion method with the elegant study by Nicolaou regarding carbanion addition to thionolactones, ${ }^{14}$ we have affected a stereoselective total synthesis of $(+)$-cis-lauthisan $[(+)-16]$ in only six linear operations (Scheme 6). (+)-Hexenyl lactone $(+)-9 a$, made in two steps $(59 \%)$ from enol ether 7 , was first saturated and then converted, using the Lawesson reagent, to thionolactone (+)-14. In only two additional steps involving: (1) treatment with ethyl lithium, followed by iodomethane, and (2) reductive removal of sulfur, $(+)$-cis-lauthisan could be accessed in good overall yield (21\% from 7$)$ and high enantioselectivity. Importantly, as determined by ${ }^{1} \mathrm{H}$ NMR, no trace of the undesired trans-oxocane was observed, with all data in good agreement with previous literature reports for this compound.

\section{Copper-Mediated Conjugate Addition Studies}

According to the original report by Still, the addition of $\mathrm{Me}_{3} \mathrm{SiLi}$-generated via the addition of MeLi to $\mathrm{Me}_{3} \mathrm{SiSiMe}_{3}$ in HMPA-to cyclohexenone occurs smoothly (Scheme 7), with HMPA acting to stabilize the silyl anion and facilitate the 1,4addition process. ${ }^{15}$ Wanting to find a more environmentallyfriendly alternative, the use of comparable additives was explored. For example, tetramethylethylenediamine (TMEDA) and dimethyltetrahydropyrimidinone (DMPU) were separately substituted into the reaction, however, neither gave any evidence of the desired conjugate addition. In support of these findings, Fleming has reported that, trimethylsilyl lithium is difficult to generate in the absence of HMPA. ${ }^{16}$
Scheme 6. Stereoselective Total Synthesis of (+)-cis-Lauthisan<smiles>CCCC1CC=CCCC(=O)O1</smiles>

$(+)-9 a$

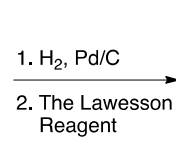

two steps, $49 \%$

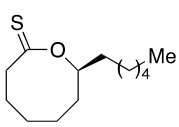

$(+)-14$

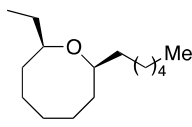

$(+)-16$

Since the trimethylsilyl anion proved troublesome to generate differently, it became necessary to explore complementary conditions that would allow for the necessary 1,4-addition of a silyl anion. Pleasingly, a search of the literature would prove useful in finding the appropriate anion and a method to perform the necessary conjugate addition. ${ }^{16}$ Of note, this method was also independently utilized by Hwu during a recent report regarding the conversion of enolates to $\beta$-silyl enones. ${ }^{17}$ Utilizing this procedure, we found that chlorodimethylphenylsilane could be treated with excess lithium metal, leading to a dark red solution of $\mathrm{PhMe}_{2} \mathrm{SiLi}$. After stirring ca. $18 \mathrm{~h}$, the anion could be transferred, via canula, to a flame dried flask containing copper (I) iodide suspended in THF at $-25^{\circ} \mathrm{C}$. After stirring for an additional $4 \mathrm{~h}$, cyclohexenone could be added dropwise to the solution of silyl cuprate followed by $\mathrm{Me}_{3} \mathrm{SiCl}$ and triethylamine after $30 \mathrm{~min}$, forming the desired $\beta$-silyl silylenol ether (17, Scheme 7). Importantly, this compound was stable to routine aqueous workup and flash column chromatography using florisil as stationary phase.

Scheme 7. Copper-Mediated, HMPA-free n+3 Ring Expansions

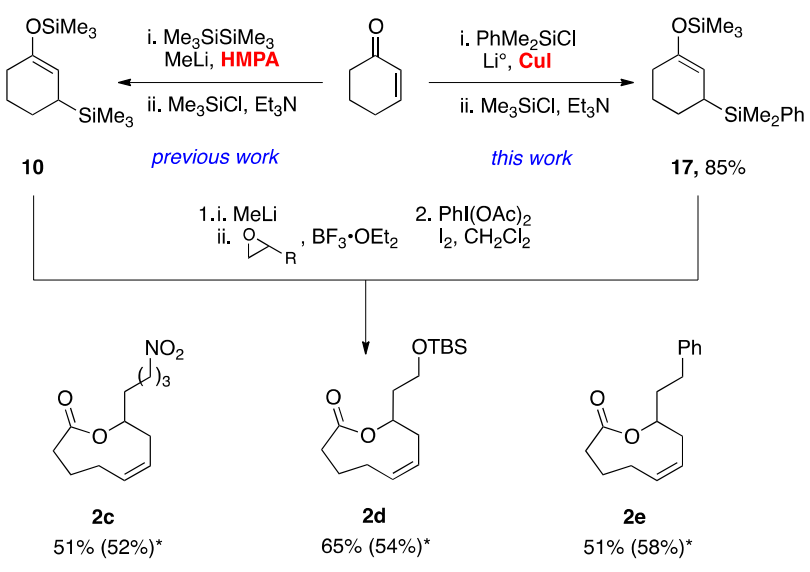

*Yields using 10 as starting material

Several aspects of this new protocol are noteworthy. In order to achieve reproducibly high yields, it was necessary to wash the $\mathrm{CuI}$ every two weeks using a soxhlet extractor (THF as solvent). As an alternative, $\mathrm{CuI} \cdot \mathrm{SMe}_{2}$ could be substituted in place of $\mathrm{CuI}$, however, the product enol ether retained an unpleasant odor, even after vacuum distillation. Comparable yields could also be achieved using diethylzinc $\left(\mathrm{Et}_{2} \mathrm{Zn}\right)$ either in place of $\mathrm{CuI}$, or with a catalytic amount of $\mathrm{CuI}$ added. Yields for this process were typically high $(75-80 \%)$ and proceeded with the main advantage being a shorter reaction time overall, compared to the cuprate method. Also of note, $\beta$-silyl silylenol ether $\mathbf{1 7}$ is stable at $-20^{\circ} \mathrm{C}$ under nitrogen for at least several months and large quantities can 
be generated and stored allowing one to consider it a stock reagent, utilized in small quantities, as needed.

When compared to the previously studied $\beta$-silyl silylenol ether 10 ${ }^{1-2}$ the steric and electronic environment surrounding the $\beta$-silicon group of $\mathbf{1 7}$ is markedly different (Scheme 7). At the onset of this work, we were not sure that a lithium enolate derived from 17 could productively interact with a mono substituted epoxide. Pleasingly, when $\mathbf{1 7}$ was treated with $\mathrm{MeLi}$ at $0{ }^{\circ} \mathrm{C}$, followed by cooling to $-78{ }^{\circ} \mathrm{C}$ and the addition of 4-phenylbutene oxide and $\mathrm{BF}_{3} \cdot \mathrm{Et}_{2} \mathrm{O}$, a hemiketal was produced in high yield (77\%). Importantly, when this intermediate was subsequently treated with $\mathrm{PhI}(\mathrm{OAc})_{2}$ and $\mathrm{I}_{2}$ at $0{ }^{\circ} \mathrm{C}$ in $\mathrm{CH}_{2} \mathrm{Cl}_{2}$, cisalkene-containing lactone $\mathbf{2 e}$ was isolated as the sole reaction product, in good overall yield (51\% from 17, Scheme 7). Encouraged by this result, two additional epoxides were screened in this new HMPA-free $\mathrm{n}+3$ reaction sequence (Scheme 7, 2a and 2d), with yields being comparable, if not better than those observed using $\beta$-silyl silylenol ether $\mathbf{1 0}$ (yields in parentheses).

\section{Conclusion}

In this study, several new epoxide examples were united with $\beta$-silyl ketone enolates for the construction, after oxidative fragmentation, of ring expanded $n+3$ lactones. As an extension of this work, lactone to lactam ring expansion was investigated, as was the stereoselective total synthesis of (+)-cis-lauthisan. In a final note, a new, cuprate-mediated and HMPA-free protocol for the generation of a $\beta$-silyl silylenol ether is described, advancing this process even more towards a robust and environmentally-friendly procedure for the construction of medium sized lactones. Additional investigations by the Maio Laboratory are currently ongoing and will be reported in due course.

\section{Acknowledgement}

The authors would like to thank the NSF for seed support for this project, as well as Drs. Amy Sarjeant (JHU), Susan Hatcher (OSU), and Phil Mortimer (JHU) for providing analytical data services (X-ray and mass analysis). We would also like to thank Drs. Maxime Siegler (JHU) for data handling, Ryan Conyers (JHU) for coordinating data retrieval, and Alvin Kalinda (JHU) for his effors regarding the reproducibility of our coppermediated conditions. WAM dedicates this manuscript to his colleague and friend, Dr. James P. Bacci (1979-2015), with deep admiration and great respect.

\section{Experimental Section}

Unless otherwise noted, reactions were performed in flame or oven dried glassware under an atmosphere of dry argon. Reaction solvents $\left(\mathrm{CH}_{2} \mathrm{Cl}_{2}\right.$, THF, and $\left.\mathrm{Et}_{2} \mathrm{O}\right)$ were purified before use via distillation. All other solvents and reagents were purchased from Sigma-Aldrich and used as received, unless otherwise specified. Thin-layer chromatography (TLC) was performed using plates precoated with silica gel $60 \AA \mathrm{F}-254(250 \mu \mathrm{m})$ and visualized by UV light, $\mathrm{KMnO}_{4}$, or anisaldehyde stains, followed by heating. ${ }^{1} \mathrm{H}$ and ${ }^{13} \mathrm{C}$ NMR spectra were recorded on a Bruker 400 (operating at $400 \mathrm{MHz}$ and $100 \mathrm{MHz}$, respectively) or Varian XL-400 operating at the same frequences, and are reported relative to residual solvent peak $\left(\delta 7.26\right.$ and $\delta 77.0$ for ${ }^{1} \mathrm{H}$ and ${ }^{13} \mathrm{C}$ in $\mathrm{CDCl}_{3}$. Data for ${ }^{1} \mathrm{H}$ NMR spectra are reported as follows: chemical shift $(\delta \mathrm{ppm})$ (multiplicity, coupling constant $(\mathrm{Hz})$, integration). Spectra obtained are described using the following abbreviations: $\mathrm{br}=$ broad, $\mathrm{s}=$ singlet, $\mathrm{d}=$ doublet, $\mathrm{t}=$ triplet, $\mathrm{q}=$ quartet, $\mathrm{m}=$ multiplet.
General Procedure. An oven dried $25 \mathrm{~mL}$ roundbottomed flask was charged with $\beta$-silyl silylenol ether $(1.0 \mathrm{mmol})$, dissolved in THF $(1.5 \mathrm{~mL})$ and cooled to $0{ }^{\circ} \mathrm{C}$. To this was added MeLi (0.63 mL, $\left.1.0 \mathrm{mmol}, 1.6 \mathrm{M}^{\text {in }} \mathrm{Et}_{2} \mathrm{O}\right)$ dropwise, turning the solution a bright bright yellow color. After $5 \mathrm{~min}$, the flask was then cooled to $-78^{\circ} \mathrm{C}$ before a solution of epoxide $(0.5 \mathrm{mmol})$ in THF $(1.5 \mathrm{~mL})$ was added via cannula. The mixture was allowed to stir for $5 \mathrm{~min}$ before $\mathrm{BF}_{3} \cdot \mathrm{Et}_{2} \mathrm{O}(60 \mu \mathrm{L}, 0.5 \mathrm{mmol}$, neat $)$ was added ( 1 drop every $4 \mathrm{sec}$ ) while cooling the needle with a piece of dry ice. After $30 \mathrm{~min}$, the reaction was quenched with the addition of phosphate buffer $(3.0 \mathrm{~mL}, \mathrm{pH} 7.0)$ and allowed to warm to rt. The crude reaction mixture was then extracted with $\mathrm{Et}_{2} \mathrm{O}(3 \times 25 \mathrm{~mL})$ and the combined organic layers dried over $\mathrm{MgSO}_{4}$ and concentrated in vacuo. The crude product was purified by silica gel chromatography $(90 \%$ hexanes, $10 \%$ ethyl acetate, $\sim 1 \% \mathrm{Et}_{3} \mathrm{~N}$ ) to yield the desired hemiketal as a colorless oil which was taken directly on to the next step without further purification.

In a second step, an oven dried $25 \mathrm{~mL}$ roundbottomed flask was charged with hemiketal $(0.1 \mathrm{mmol})$, dissolved in $\mathrm{CH}_{2} \mathrm{Cl}_{2}(8$ $\mathrm{mL}$ ) and cooled to $0{ }^{\circ} \mathrm{C}$. To this solution was added, sequentially, $\mathrm{PhI}(\mathrm{OAc})_{2}(0.048 \mathrm{~g}, 0.15 \mathrm{mmol})$ and then $\mathrm{I}_{2}(0.033 \mathrm{~g}, 0.13$ $\mathrm{mmol})$, turning the solution a dark purple color. The reaction was stirred for $5 \mathrm{hr}$ at $0{ }^{\circ} \mathrm{C}$ before being quenched with a saturated aqueous solution of sodium thiosulfate, turning the solution a light pink color. The crude mixture was then extracted with $\mathrm{CH}_{2} \mathrm{Cl}_{2}(3 \times 25 \mathrm{~mL})$, and the combined organic layers were dried over $\mathrm{MgSO}_{4}$ and concentrated in vacuo. The crude product was purified by silica gel chromatography $(90 \%$ hexanes, $10 \%$ ethyl acetate) to afford the desired lactone as a colorless (often volatile) oil.

Lactone 2a. ${ }^{1} \mathrm{H}$ NMR $\left(\mathrm{CDCl}_{3}\right) \delta$ 5.50-5.46 (m, 2H), 4.95-4.89 $(\mathrm{m}, 1 \mathrm{H}), 3.90-3.86(\mathrm{~m}, 1 \mathrm{H}), 2.47-2.42(\mathrm{~m}, 1 \mathrm{H}), 2.34-2.23(\mathrm{~m}$, $3 \mathrm{H}), 2.06-2.01(\mathrm{~m}, 3 \mathrm{H}), 1.85-1.59(\mathrm{~m}, 3 \mathrm{H}), 1.15(\mathrm{~d}, J=8.0 \mathrm{~Hz}$, $3 \mathrm{H}), 0.88$ (s, 9H), 0.05 (s, 3H), $0.03(\mathrm{~s}, 3 \mathrm{H}) ;{ }^{13} \mathrm{C} \mathrm{NMR}\left(\mathrm{CDCl}_{3}\right)$ $\delta 174.2,134.4,124.9,70.9,65.7,45.0,34.8,33.6,26.4,25.9$, $24.5,18.0,-4.2,-4.8$; IR (neat) $3011,2953,2930,2857,1743$, $1448,1359,1257,1139,1107,836 \mathrm{~cm}-1$; HRMS (EI), m/z $(\mathrm{M}+\mathrm{Na})$ calcd. 335.2013 for $\mathrm{C}_{17} \mathrm{H}_{32} \mathrm{O}_{3} \mathrm{SiNa}^{+}$, found 335.2016. (note: unfortunately, the optical rotation for this compound was not obtained)

Lactone 2b. ${ }^{1} \mathrm{H}$ NMR $\left(\mathrm{CDCl}_{3}\right) \delta$ 5.52-5.44 (m, 2H), 4.89-4.83 $(\mathrm{m}, 1 \mathrm{H}), 3.41-3.33(\mathrm{~m}, 2 \mathrm{H}), 2.48-2.24(\mathrm{~m}, 5 \mathrm{H}), 2.08-2.01(\mathrm{~m}$, $3 \mathrm{H}), 1.92-1.77(\mathrm{~m}, 2 \mathrm{H}) ;{ }^{13} \mathrm{C} \mathrm{NMR}\left(\mathrm{CDCl}_{3}\right) \delta 174.2,134.8,124.3$, 70.6, 40.0, 34.0, 33.7, 33.5, 26.4, 25.3; IR (neat) 2949, 2099, $1742,1448,1261,1213,1138,727 \mathrm{~cm}^{-1}$; HRMS (FAB) $\mathrm{m} / \mathrm{z}$ $(\mathrm{M}+\mathrm{H})$ calcd. 210.1243 for $\mathrm{C}_{10} \mathrm{H}_{15} \mathrm{~N}_{3} \mathrm{O}_{2}^{+}$, found 210.1244.

Lactone 2c. ${ }^{1} \mathrm{H}$ NMR $\left(\mathrm{CDCl}_{3}\right) \delta 5.50-5.46(\mathrm{~m}, 2 \mathrm{H}), 4.78-4.72$ (m, 1H), 4.38 (t, $J=6.8 \mathrm{~Hz}, 2 \mathrm{H}), 2.49-2.21(\mathrm{~m}, 4 \mathrm{H}), 2.80-1.97$ $(\mathrm{m}, 4 \mathrm{H}), 1.82-1.42(\mathrm{~m}, 6 \mathrm{H}) ;{ }^{13} \mathrm{C} \mathrm{NMR}\left(\mathrm{CDCl}_{3}\right) \delta 174.5,134.6$, 124.5, 75.4, 72.6, 34.0, 33.6, 26.9, 26.5, 25.3, 22.5 (note: one carbon resonance is missing due to accidental overlap); IR (neat) 2951, 1737, 1552, 1448, 1356, 1215, 1139, $730 \mathrm{~cm}^{-1}$; HRMS (EI), $\mathrm{m} / \mathrm{z}(\mathrm{M}+\mathrm{Na})$ calcd. 264.1206 for $\mathrm{C}_{12} \mathrm{H}_{19} \mathrm{NO}_{4} \mathrm{Na}^{+}$, found 264.1200.

Lactone 2d. Has been reported previously by our laboratory. See reference $1 b$.

Lactone 2e. Has been reported previously by our laboratory. See reference 1a. 
Lactone 9a. $[\alpha]_{\mathrm{D}}^{23}+22.5^{\circ}\left(\mathrm{c}=0.53, \mathrm{CHCl}_{3}\right) ;{ }^{1} \mathrm{H} \mathrm{NMR}$ $\left(\mathrm{CDCl}_{3}\right) \delta$ 5.81-5.70 (m, 2H), 4.58-4.52 (m, 1H), 2.88-2.77 (m, $1 \mathrm{H}), 2.71$ (ddd, $J=13.2,6.0,2.8 \mathrm{~Hz}, 1 \mathrm{H}), 2.46-2.38(\mathrm{~m}, 1 \mathrm{H})$, 2.29 (ddd, $J=13.6,11.6,4.8 \mathrm{~Hz}, 1 \mathrm{H}), 2.13-2.05$ (m, 2H), 1.67$1.59(\mathrm{~m}, 1 \mathrm{H}), 1.55-1.47(\mathrm{~m}, 1 \mathrm{H}), 1.43-1.22(\mathrm{~m}, 8 \mathrm{H}), 0.86(\mathrm{t}, J=$ $7.2 \mathrm{~Hz}, 3 \mathrm{H}) ;{ }^{13} \mathrm{C}$ NMR $\left(\mathrm{CDCl}_{3}\right) \delta 177.3,132.5,128.4,78.4$, $37.8,34.7,34.4,31.7,28.9,25.7,24.3,22.5,14.0$; IR (neat) 3018, 2932, 2858, 1749, 1454, 1323, 1215, 1149, $1053 \mathrm{~cm}^{-1}$; HRMS (CI), m/z (M+Na) calcd. 233.1512 for $\mathrm{C}_{13} \mathrm{H}_{22} \mathrm{O}_{2} \mathrm{Na}^{+}$, found 233.1517 .

Lactone 9b. ${ }^{1} \mathrm{H}$ NMR $\left(\mathrm{CDCl}_{3}\right) \delta$ 5.90-5.72 (m, 2H), 4.83-4.77 $(\mathrm{m}, 1 \mathrm{H}), 2.87-2.62(\mathrm{~m}, 6 \mathrm{H}), 2.38-2.31(\mathrm{~m}, 1 \mathrm{H}), 2.25-2.14(\mathrm{~m}$, $1 \mathrm{H}) ;{ }^{13} \mathrm{C} \mathrm{NMR}\left(\mathrm{CDCl}_{3}\right) \delta 175.6,134.0,126.5,116.1,71.6,37.6$, 33.3, 24.3, 23.6; IR (neat) 2928, 2866, 2291, 1751, $1461 \mathrm{~cm}^{-1}$; HRMS (EI), $\mathrm{m} / \mathrm{z}(\mathrm{M}+\mathrm{Na})$ calcd. 188.0682 for $\mathrm{C}_{9} \mathrm{H}_{11} \mathrm{NO}_{2} \mathrm{Na}^{+}$, found 188.0691

Lactone 9c. ${ }^{1} \mathrm{H} \mathrm{NMR}\left(\mathrm{CDCl}_{3}\right) \delta$ 7.93-7.91 (m, $\left.1 \mathrm{H}\right)$, 7.55-7.35 $(\mathrm{m}, 3 \mathrm{H}), 5.84-5.73(\mathrm{~m}, 2 \mathrm{H}), 4.92-4.86(\mathrm{~m}, 1 \mathrm{H}), 3.29-3.14(\mathrm{~m}$, $2 \mathrm{H}), 2.87-2.78(\mathrm{~m}, 1 \mathrm{H}), 2.72-2.66(\mathrm{~m}, 1 \mathrm{H}), 2.61-2.53(\mathrm{~m}, 1 \mathrm{H})$, 2.30-2.21 (m, 2H), 2.16-2.09 (m, 1H); ${ }^{13} \mathrm{C}$ NMR $\left(\mathrm{CDCl}_{3}\right) \delta$ $176.6,149.6,133.0,132.9,132.6,132.5,127.8,127.7,124.7$, 77.2, 37.6, 37.4, 34.4, 24.3; IR (neat) 2938, 1747, 1526, 1348, 1215, $1055 \mathrm{~cm}^{-1}$; HRMS (CI) $\mathrm{m} / \mathrm{z}(\mathrm{M}+\mathrm{Na})$ calcd. 284.0893 for $\mathrm{C}_{14} \mathrm{H}_{15} \mathrm{NO}_{4} \mathrm{SiNa}^{+}$, found 284.0890.

Lactone 9d. ${ }^{1} \mathrm{H}$ NMR $\left(\mathrm{CDCl}_{3}\right) \delta$ 5.82-5.69 (m, 2H), 4.66-4.60 (m, $1 \mathrm{H}), 3.44-3.33(\mathrm{~m}, 2 \mathrm{H}), 2.83-2.68(\mathrm{~m}, 2 \mathrm{H}), 2.50-2.43(\mathrm{~m}$, $1 \mathrm{H}), 2.34-2.27(\mathrm{~m}, 1 \mathrm{H}), 2.14-2.05(\mathrm{~m}, 2 \mathrm{H}), 1.91-1.75(\mathrm{~m}, 2 \mathrm{H})$; ${ }^{13} \mathrm{C} \mathrm{NMR}\left(\mathrm{CDCl}_{3}\right) \delta 176.7,132.8,127.7,75.1,47.9,37.6,34.2$, 33.8, 24.2; IR (neat) 2939, 2100, 1748, 1215, $1057 \mathrm{~cm}^{-1}$; HRMS (EI), $\mathrm{m} / \mathrm{z}(\mathrm{M}+\mathrm{Na})$ calcd. 218.0899 for $\mathrm{C}_{9} \mathrm{H}_{13} \mathrm{~N}_{3} \mathrm{O}_{2} \mathrm{Na}^{+}$, found 218.0913 .

Lactone 9e. ${ }^{1} \mathrm{H}$ NMR $\left(\mathrm{CDCl}_{3}\right) \delta$ 5.82-5.69 (m, 2H), 4.57-4.52 (m, 1H), 3.35-3.30 (m, 2H), 2.87-2.68 (m, 2H), 2.50-2.42 (m, $1 \mathrm{H}), 2.33-2.26(\mathrm{~m}, 1 \mathrm{H}), 2.13-2.02(\mathrm{~m}, 2 \mathrm{H}), 1.80-1.59(\mathrm{~m}, 4 \mathrm{H})$; ${ }^{13} \mathrm{C}$ NMR $\left(\mathrm{CDCl}_{3}\right) \delta 177.2,132.8,128.0,77.5,50.8,37.7,34.4$, 31.5, 25.2, 24.3; IR (neat) 3030, 2946, 2872, 2097, 1743, 1454, $1314,1211,1146,1053,726 \mathrm{~cm}^{-1}$; HRMS (EI), $\mathrm{m} / \mathrm{z}(\mathrm{M}+\mathrm{Na})$ calcd. 232.1056 for $\mathrm{C}_{10} \mathrm{H}_{15} \mathrm{~N}_{3} \mathrm{O}_{2} \mathrm{Na}^{+}$, found 232.1048.

Lactone 11. A $10 \mathrm{~mL}$ roundbottomed flask was charged with lactone $2 \mathbf{b}(0.006 \mathrm{~g}, 0.03 \mathrm{mmol})$ and the Lindlar catalyst $(\sim 0.002$ g, $30 \%$ by weight) before being dissolved in ethanol $(2 \mathrm{~mL})$. The flask was then covered with a septa and evacuated using a vacuum pump, replacing the inner atmosphere with a blanket of hydrogen using a balloon. After $2 \mathrm{~h}$ the reaction mixture was diluted with $\mathrm{CH}_{2} \mathrm{Cl}_{2}(1 \mathrm{~mL})$, passed over celite, and then concentrated in vacuo to afford the desired lactone as a colorless oil $(0.004 \mathrm{~g}, 80 \%)$. ${ }^{1} \mathrm{H}$ NMR $\left(\mathrm{CDCl}_{3}\right) \delta 5.49-5.47$ (m, 2H), 4.89$4.84(\mathrm{~m}, 1 \mathrm{H}), 2.49-2.22(\mathrm{~m}, 5 \mathrm{H}), 2.08-1.88(\mathrm{~m}, 3 \mathrm{H}), 1.83-1.73$ $(\mathrm{m}, 2 \mathrm{H}), 1.43(\mathrm{~s}, 2 \mathrm{H})$. Because of the polar nature of this compound, it was protected as its BOC-derivative for further characterization.

A $15 \mathrm{~mL}$ roundbottomed flask was charged with $11(0.029 \mathrm{~g}$, $0.14 \mathrm{mmol})$ and dissolved in ethyl acetate $(2 \mathrm{~mL})$. To this was added the Lindlar catalyst $(\sim 0.005 \mathrm{~g}, 30 \%$ by weight $)$ and BOC anhydride $(0.036 \mathrm{~g}, 0.17 \mathrm{mmol})$. The flask was then covered with a septa and evacuated using a vacuum pump, replacing the inner atmosphere with a blanket of hydrogen using a balloon. After 5 $\mathrm{h}$, the reaction mixture was diluted with $\mathrm{CH}_{2} \mathrm{Cl}_{2}(1 \mathrm{~mL})$, passed over celite, and concentrated in vacuo. The crude product was purified by silica gel chromatography $(70 \%$ hexanes, $30 \%$ ethyl acetate) to afford the desired BOC-protected lactone as a colorless oil $(0.036 \mathrm{~g}, 92 \%) .{ }^{1} \mathrm{H}$ NMR $\left(\mathrm{CDCl}_{3}\right) \delta$ 5.49-5.46 (m, $2 \mathrm{H}), 4.82-4.76(\mathrm{~m}, 1 \mathrm{H}), 3.38-3.32(\mathrm{~m}, 1 \mathrm{H}), 3.08-3.03(\mathrm{~m}, 1 \mathrm{H})$, 2.48-2.21 (m, 4H), 2.07-1.97 (m, 3H), 1.82-1.73 (m, 3H), $1.42(\mathrm{~s}$, 9H) (note: the NH proton is likely overlaping with the chloroform peak at 7.26); ${ }^{13} \mathrm{C}$ NMR $\left(\mathrm{CDCl}_{3}\right) \delta 174.6,155.8,134.6$, 124.5, 79.2, 71.2, 37.1. 34.5, 33.9, 33.5, 28.3, 26.5, 25.3; IR (neat) $3413,2981,1811,1742,1716,1512,1371 \mathrm{~cm}^{-1}$; HRMS (EI), $\mathrm{m} / \mathrm{z}(\mathrm{M}+\mathrm{Na})$ calcd. 306.16757 for $\mathrm{C}_{15} \mathrm{H}_{25} \mathrm{NO}_{4} \mathrm{Na}^{+}$, found 306.16750 .

Lactam 12. A $10 \mathrm{~mL}$ rounbottomed flask was charged with lactone $9 \mathrm{~d}(0.03 \mathrm{~g}, 0.2 \mathrm{mmol})$ and dissolved in THF $(3 \mathrm{~mL})$. To this was added $\mathrm{PPh}_{3}(0.081 \mathrm{~g}, 0.23 \mathrm{mmol})$ and $\mathrm{H}_{2} \mathrm{O}(0.1 \mathrm{~mL})$ before the contents of the flask were heated to $50{ }^{\circ} \mathrm{C}$ in an oil bath. After $18 \mathrm{hr}$, the reaction was concentrated in vacuo and columned directly without workup $\left(92 \% \mathrm{CH}_{2} \mathrm{Cl}_{2}, 7 \% \mathrm{MeOH}, 1 \%\right.$ $\left.\mathrm{NH}_{4} \mathrm{OH}\right)$ to afford the desired lactam as a colorless oil $(0.018 \mathrm{~g}$, 69\%). ${ }^{1} \mathrm{H}$ NMR $\left(\mathrm{CDCl}_{3}\right) \delta 5.60-5.53(\mathrm{~m}, 3 \mathrm{H}), 4.13-4.04(\mathrm{~m}, 1 \mathrm{H})$, 3.49-3.40 (m, 1H), 3.19 (br s, $1 \mathrm{H}), 2.74$ (br s, $1 \mathrm{H}), 2.38-1.99(\mathrm{~m}$, $5 \mathrm{H}), 1.85-1.61(\mathrm{~m}, 2 \mathrm{H}), 1.26-1.07(\mathrm{~m}, 1 \mathrm{H}) ;{ }^{13} \mathrm{C} \mathrm{NMR}\left(\mathrm{CDCl}_{3}\right) \delta$ 173.0, 129.7, 127.5, 69.4, 36.1, 34.2, 24.1 (note: two carbon resonances are missing due to accidental overlap.); IR (neat) 3300, 2927, 2853, 1640, 1547, $1444 \mathrm{~cm}^{-1}$; HRMS (EI), $\mathrm{m} / \mathrm{z}$ $(\mathrm{M}+\mathrm{Na})$ calcd. 192.0995 for $\mathrm{C}_{9} \mathrm{H}_{15} \mathrm{NO}_{2} \mathrm{Na}^{+}$, found 192.0993 .

Lactam 13. Was prepared in a similar manner to lactam 12. ${ }^{1} \mathrm{H}$ NMR $\left(\mathrm{CDCl}_{3}\right) \delta 5.77(\mathrm{~s}, 1 \mathrm{H}), 5.63-5.53(\mathrm{~m}, 2 \mathrm{H}), 3.88-3.87$ $(\mathrm{m}, 1 \mathrm{H}), 3.23-3.14(\mathrm{~m}, 2 \mathrm{H}), 2.38-2.04(\mathrm{~m}, 6 \mathrm{H}), 1.66-1.24(\mathrm{~m}$, $4 \mathrm{H}) ;{ }^{13} \mathrm{C} \mathrm{NMR}\left(\mathrm{CDCl}_{3}\right) \delta 173.2,129.6,128.0,77.2,70.4,39.8$, 37.1, 31.5, 29.9, 25.2; IR (neat) 3300, 2927, 2862, 1640, 1556, $1454 \mathrm{~cm}^{-1}$; HRMS (FAB), m/z (M+H) calcd. 184.1338 for $\mathrm{C}_{10} \mathrm{H}_{18} \mathrm{NO}_{2}^{+}$, found 184.1346 .

Thionolactone 14. Lactone (+)-9a $(0.128 \mathrm{~g}, 0.61 \mathrm{mmol})$ was placed in a $25 \mathrm{~mL}$ roundbottomed flask with THF $(7 \mathrm{~mL})$ along with palladium on carbon ( $0.020 \mathrm{~g}, 20 \%$ by weight). The flask was then covered with a septa and evacuated using a vacuum pump, replacing the inner atmosphere with a blanket of hydrogen using a balloon. The reaction was monitored by GC and found to be complete after $15 \mathrm{~h}$. The solution was then concentrated in vacuo to dryness and passed over a plug of silica using hexanes to afford the saturated lactone as a colorless oil $(0.088 \mathrm{~g}, 70 \%)$. $[\alpha]_{\mathrm{D}}^{25}+26.15^{\circ}\left(\mathrm{c}=0.325, \mathrm{CHCl}_{3}\right) ;{ }^{1} \mathrm{H}$ NMR $\left(\mathrm{CDCl}_{3}\right) \delta 4.57-4.50$ $(\mathrm{m}, 1 \mathrm{H}), 2.57-2.43(\mathrm{~m}, 2 \mathrm{H}), 1.95-1.87(\mathrm{~m}, 1 \mathrm{H}), 1.85-1.79(\mathrm{~m}$, $1 \mathrm{H}), 1.78-1.55(\mathrm{~m}, 4 \mathrm{H}), 1.54-1.40(\mathrm{~m}, 4 \mathrm{H}), 1.34-1.22(\mathrm{~m}, 8 \mathrm{H})$, $0.88(\mathrm{t}, J=7.2 \mathrm{~Hz}, 3 \mathrm{H}) ;{ }^{13} \mathrm{C} \mathrm{NMR}\left(\mathrm{CDCl}_{3}\right) \delta 177.0,78.7,37.3$, 35.6, 32.4, 31.7, 29.1, 28.9, 26.4, 25.7, 23.9, 22.5, 14.0; IR (neat) 2929, 2858, 1732, 1456, 1232, 1119, $1006 \mathrm{~cm}^{-1}$; HRMS (CI), m/z (M) calcd. 212.1770 for $\mathrm{C}_{13} \mathrm{H}_{24} \mathrm{O}_{2}^{+}$, found 212.1785

In a second setep, the saturated lactone $(0.084 \mathrm{~g}, 0.40 \mathrm{mmol})$ was placed in a $25 \mathrm{~mL}$ roundbottom flask with toluene $(2.5 \mathrm{~mL}$, anhydrous) before the Lawesson reagent $(0.160 \mathrm{~g}, 0.40 \mathrm{mmol})$ was added in one portion. The contents of the flask were then heated to reflux for $1 \mathrm{~h}$ and then allowed to slowly cool to rt. The cooled solution was then purified directly without workup (98\% hexanes, $2 \%$ ethyl acetate) to afford the desired lactone as a colorless oil $(0.064 \mathrm{~g}, 71 \%)$. $[\alpha]_{\mathrm{D}}^{25}+17.22^{\circ}\left(\mathrm{c}=1.15, \mathrm{CHCl}_{3}\right) ;{ }^{1} \mathrm{H}$ NMR $\left(\mathrm{CDCl}_{3}\right) \delta$ 4.80-4.84 (m, 1H), 3.18-3.12 (m, 1H), 3.00$2.93(\mathrm{~m}, 1 \mathrm{H}), 2.02-1.67(\mathrm{~m}, 6 \mathrm{H}), 1.66-1.55(\mathrm{~m}, 2 \mathrm{H}), 1.54-1.40$ (m, 2H), 1.38-1.22 (m, 8H), $0.87(\mathrm{t}, J=7.2 \mathrm{~Hz}, 3 \mathrm{H}) ;{ }^{13} \mathrm{C}$ NMR $\left(\mathrm{CDCl}_{3}\right) \delta$ 229.1, 85.2, 44.1, 37.5, 35.6, 32.4, 31.6, 29.0, 26.2, 25.8, 24.0, 22.5, 14.0; IR (neat) 2926, 2360, 1458, 1302, 1232, $1081 \mathrm{~cm}^{-1}$; HRMS (CI), m/z (M) calcd. 228.1542 for $\mathrm{C}_{13} \mathrm{H}_{24} \mathrm{OS}^{+}$, found 228.1554 . 
(+)-cis-Lauthisan (16). Thionolactone $14(0.060$ g, 0.26 mmol) was placed in a $25 \mathrm{~mL}$ roundbottomed flask with THF (3 $\mathrm{mL}$ ) and then cooled to $-78{ }^{\circ} \mathrm{C}$. To this solution was added ethyllithium $(0.788 \mathrm{~mL}, 0.394 \mathrm{mmol}, 0.5 \mathrm{M}$ in cyclohexane/benzene) slowly via syringe. The reaction was allowed to stir for $10 \mathrm{~min}$ at $-78{ }^{\circ} \mathrm{C}$ before iodomethane $(0.033 \mathrm{~mL}, 0.53 \mathrm{mmol})$ was added in one portion. After warming to $\mathrm{rt}$, the reaction mixture was quenced with water and extracted with ether $(3 \times 25$ $\mathrm{mL}$ ). The combined organic layers were then dried over $\mathrm{MgSO}_{4}$ and concentrated in vacuo. The crude material was purified by silica gel chromatography ( $95 \%$ hexanes, $5 \%$ ethyl acetate) to yied the desired cyclic ether as a colorless oil $(0.055 \mathrm{~g}, 77 \%)$. This material was found to be unstable and taken directly on to the next step without characterization.

In a second step, this cyclic ether $(0.045 \mathrm{~g}, 0.17 \mathrm{mmol})$ was placed in a $25 \mathrm{~mL}$ roundbottomed flask with toluene $(5 \mathrm{~mL}$, anyhdrous) and treated with tributyltin hydride $(0.111 \mathrm{~mL}, 0.41$ mmol) and a catalytic amount of AIBN $(0.005 \mathrm{~g})$. The contents of the flask were then heated to reflux for $1.5 \mathrm{~h}$ after which the solution was cooled to rt, passed over a plug of silica gel using hexanes, and concentrated in vacuo. The crude reaction mixture was then purified by silica gel chromatography $(95 \%$ hexanes, $5 \%$ ethyl acetate) to yied the desired compound as a colorless oil $(0.035 \mathrm{~g}, 95 \%) .[\alpha]_{\mathrm{D}}^{24}+14.6^{\circ}\left(\mathrm{c}=0.15, \mathrm{CHCl}_{3}\right) ;{ }^{1} \mathrm{H} \mathrm{NMR}$ $\left(\mathrm{CDCl}_{3}\right) \delta 3.44-3.38(\mathrm{~m}, 1 \mathrm{H}), 3.36-3.30(\mathrm{~m}, 1 \mathrm{H}), 1.82-1.56(\mathrm{~m}$, $5 \mathrm{H}), 1.55-1.33(\mathrm{~m}, 9 \mathrm{H}), 1.32-1.20(\mathrm{~m}, 8 \mathrm{H}), 0.93(\mathrm{t}, J=7.6 \mathrm{~Hz}$, $3 \mathrm{H}), 0.88(\mathrm{t}, J=7.2 \mathrm{~Hz}, 3 \mathrm{H}) ;{ }^{13} \mathrm{C}$ NMR $\left(\mathrm{CDCl}_{3}\right) \delta 81.1,79.6$, $37.0,33.6,33.3,31.9,29.8,29.5,27.0,26.3,24.0,22.6,14.11$, 10.9 (note: similar to known literature reports, two carbon resonances are missing due to accidental overlap. For example, see reference 13i); IR (neat) 2926, 2856, 1457, 1340, $1089 \mathrm{~cm}^{-1}$; HRMS (CI), m/z (M) calcd. 226.2291 for $\mathrm{C}_{15} \mathrm{H}_{30} \mathrm{O}^{+}$, found 226.2284 .

$\beta$-silyl silylenol ether 17. In an oxygen purged, nitrogen filled glove bag, lithium ribbon $(0.51 \mathrm{~g}, 73.0 \mathrm{mmol})$ was carefully cut and added to a flame dried $100 \mathrm{~mL}$ flask. To this, was added chlorodimethylphenylsilane (1.78 g, $10.4 \mathrm{mmol})$ and THF (17 $\mathrm{mL}$ ), which produced a dark red solution. After being allowed to stir at rt overnight (ca. $18 \mathrm{~h}$ ), the silyl anion was transferred, via cannula, to a $50 \mathrm{~mL}$ roundbottom flask at $-25{ }^{\circ} \mathrm{C}$ containing freshly purified $\mathrm{CuI}(0.99 \mathrm{~g}, 5.2 \mathrm{mmol})$. After an additional $4 \mathrm{~h}$ of stirring, cyclohexenone $(0.50 \mathrm{~g}, 5.2 \mathrm{mmol})$ in THF $(3 \mathrm{~mL})$ was added dropwise, followed by triethylamine $(1.4 \mathrm{~mL}, 16.0 \mathrm{mmol})$ and trimethylsilyl chloride $(2.0 \mathrm{~mL}, 16.0 \mathrm{mmol})$ after $30 \mathrm{~min}$. Finally, after one additional hour of stirring, the reaction was was warmed to $0{ }^{\circ} \mathrm{C}$ and poured into a separatory funnel containing $100 \mathrm{~mL}$ of ice chilled hexanes. The organic layer was quickly washed, successively, with a saturated aqueous solution of $\mathrm{NH}_{4} \mathrm{Cl}(2 \times 40 \mathrm{~mL})$, brine $(30 \mathrm{~mL})$ and deionized water $(2 \times 30$ $\mathrm{mL}$ ). The organic layer was then dried over $\mathrm{MgSO}_{4}$, filtered, and concentrated in vacuo. The crude product was purified by Florisil chromatography ( $70 \%$ hexanes, $30 \%$ ethyl acetate) to yield the desired $\beta$-silyl silylenol ether (2) as a slightly yellow oil (1.34 g, $85 \%) .{ }^{1} \mathrm{H}$ NMR $\left(\mathrm{CDCl}_{3}\right) \delta$ 7.59-7.54 (m, 2H), 7.44-7.37 (m, 3H), 4.89-4.88 (m, 1H), 2.02-1.98 (m, 2H), 1.81-1.71 (m, 3H), 1.59$1.55(\mathrm{~m}, 1 \mathrm{H}), 1.39-1.34(\mathrm{~m}, 1 \mathrm{H}), 0.35(\mathrm{~s}, 3 \mathrm{H}), 0.34(\mathrm{~s}, 3 \mathrm{H}), 0.23$ $(\mathrm{s}, 9 \mathrm{H}) ;{ }^{13} \mathrm{C} \mathrm{NMR}\left(\mathrm{CDCl}_{3}\right) \delta 149.6,138.2,133.9,128.9,127.7$, 104.7, 29.9, 23.7, 23.6, 23.5, 0.4, -4.8, -4.9. IR (neat) 3068, 2956, 2930, 2856, 1655, 1427, 1365, 1251, 1187, 1113, 1029, $987 \mathrm{~cm}^{-1}$; HRMS (EI) $\mathrm{m} / \mathrm{z}$ (M) calcd. 304.1679 for $\mathrm{C}_{17} \mathrm{H}_{28} \mathrm{OSi}_{2}{ }^{+}$, found 304.1643 .

\section{References}

${ }^{1}$ (a) Hatcher, M.; Borstnik, K.; Posner, G. H. Tetrahedron Lett. 2003, 44, 5407. (b) Posner, G. H.; Hatcher, M. A.; Maio, W. A. Org. Lett. 2005, 7, 4301.

${ }^{2}$ Maio, W. A.; Posner, G. H. Sinishtaj, S. Org. Lett. 2007, 9, 2673.

${ }^{3}$ Posner, G. H.; Wang, Q.; Halford, B.; Elias, J.; Maxwell, J.

Tetrahedron Lett. 2000, 41, 9655.

${ }^{4}$ Alonso-Cruz, C. R.; Kennedy, A. R.; Rodrĩguez, M. S.; Suárez,

E. Tetrahedron Lett. 2007, 48, 7207.

${ }^{5}$ For example, see: (a) Kaino, M.; Naruse, Y.; Ishihara, K.; Yamamoto, H. J. Org. Chem. 1990, 55, 5814. (b) Courtneidge, J.; Lusztyk, J.; Pagé, D. Tetrahedron Lett. 1994, 35, 1003. (c) Ochiai, M.; Iwaki, S.; Ukita, T.; Nagao, Y. Chem. Lett. 1987, 133.

${ }^{6}$ Kawamura, T.; Meakin, P.; Kochi, J. J. Am. Chem. Soc. 1972, 94, 8065 .

${ }^{7}$ Epoxides utilized in this study were synthesized according to known literature procedures.

8 The non-racemic (S)-1,2-epoxyoctane used to prepare lactone 9a in high enantiomeric excess was generated by kinetic resolution using the Jacobsen $\operatorname{CoIII}(\mathrm{AcOH})$ catalyst, $[\alpha]_{\mathrm{D}}^{24}-8.9^{\circ}\left(\mathrm{c}=2.05, \mathrm{CHCl}_{3}\right)$, lit. $[\alpha]_{\mathrm{D}}^{24}-8.9^{\circ}\left(\mathrm{c}=1.8, \mathrm{CHCl}_{3}\right)$. See: Schaus, S. E.; Brandes, B. D.; Larrow, J. F.; Tokunaga, M.; Hansen, K. B.; Gould, A. E.; Furrow, M. E.; Jacobsen, E. N. J. Am. Chem. Soc. 2002,124, 1307.

${ }^{9}$ For related work, see: (a) Derrer, S.; Feeder, N.; Teat, S. J.; Davies, J. E.; Holmes, A. B. Tetrahedron Lett. 1998, 39, 9309.

(b) Ohara, T.; Kume, M.; Narukawa, Y.; Motokawa, K.; Uotani, K.; Nakai, H. J. Org. Chem. 2002, 67, 9146.

10 Corey, E. J.; Nicolaou, K. C.; Balanson, R. D.; Machida, Y. Synthesis, 1975, 590.

${ }^{11}$ Corey, E. J., Brunelle, D. J., Nicolaou, K. C. J. Am. Chem. Soc. 1977, 99, 7359.

12 Irie, T.; Suzuki, M.; Masamune, T. Tetrahedron Lett. 1965, 6, 1091.

${ }^{13}$ For previous syntheses, see: (a) Rhee, H. J.; Beom, H. Y.; Kim, H.-D. Tetrahedron Lett. 2004, 45, 8019. (b) Kim, H.; ZianiCherif, C.; Oh, J.; Cha, J. K.; J. Org. Chem. 1995, 60, 792. (c) Paquette, L. A.; Sweeney, T. J. Tetrahedron 1990, 46, 4487. (d) Tsushima, K.; Murai, A. Chem. Lett. 1990, 761. (e) Paquette, L. A.; Sweeney, T. J. J. Org. Chem. 1990, 55, 1703. (f) Kotsuki, H.; Ushio, Y.; Kadota, I.; Ochi, M. J. Org. Chem. 1989, 54, 5153. (g) Carling, R. W.; Holmes, A. B. J. Chem. Soc., Chem. Commun. 1986, 565. (h) Suh, Y.-G.; Koo, B.-A.; Kim, E.-N.; Choi, N.-S. Tetrahedron Lett. 1995, 36, 2089. (i) Carreño, M. C.; Mazery, R. D.; Urbano, A.; Colobert, F.; Solladié, G. Org. Lett. 2005, 7, 2039. (j) Gloria Hernández-Torres, G.; Mateo, J.; Urbano, A.; Carreño, M. C. Eur. J. Org. Chem. 2013, 6259.

14 (a) Nicolaou, K. C. Hwang, C.-K.; Nugiel, D. A. J. Am. Chem. Soc. 1989, 111, 4136. (b) Nicolaou, K. C.; Hwang, C.-K.;

Duggan, M. E.; Nugiel, D. A.; Abe, Y.; Reddy, K. B.; DeFrees,

S. A.; Reddy, D. R.; Awartani, R. A.; Conley, S. R.; Rutjes, F. P.

J. T. J. Am. Chem. Soc. 1995, 117, 10227.

15 Still, W. C. J. Org. Chem. 1976, 41, 3063.

16 Ager, D. J.; Fleming, I.; Patel, S. K. J. Chem. Soc. Perkin Trans. I. 1981, 2520.

${ }^{17}$ Hwu, L. R.; Chen, C. H.; Hsu, C.-I.; Das, A. R.; Li, Y. C.; Lin, L. C. Org. Lett. 2008, 10, 1913. 
Copper and silicon mediated, HMPA-free, $n+3$ ring expansions for the construction of Leave this area blank for abstract info. medium sized lactones and lactams: short synthesis of (+)-cis-Lauthisan

Gary H. Posner, ${ }^{a}$ Mark A. Hatcher, ${ }^{b}$ and William A. Maio ${ }^{c}$

${ }^{a}$ Department of Chemistry, Johns Hopkins University, Baltimore, MD 21210, United States

GlaxoSmithKline, 5 Moore Drive, Research Triangle Park, NC 27709, United States

Department of Chemistry and Biochemistry, New Mexico State University, Las Cruces, NM 88003, United States

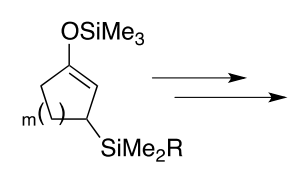

$\mathrm{R}=\mathrm{Me}, \mathrm{Ph}$

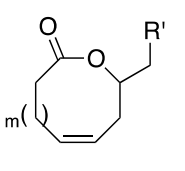

new lactone<smiles>O=C1CC/C=C\CC(O)CCCCCC1</smiles>

ring expanded lactams

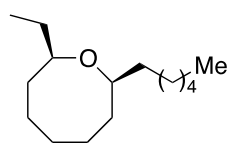

natural product total synthesis 